INTERNATIONAL JOURNAL OF RESEARCHES IN BIOSCIENCES, AGRICULTURE AND TECHNOLOGY (c) VISHWASHANTI MULTIPURPOSE SOCIETY (Global Peace Multipurpose Society) R. No. MH-659/13(N) www.ijrbat.in

\title{
EVALUATION OF MICRONUTRIENT STATUS OF SOILS OF UMRI VILLAGE, SAONER TEHSIL, NAGPUR DISTRICT, MAHARASHTRA, INDIA
}

\author{
R R Gupta ${ }^{1}$ And A S Mahakalkar ${ }^{2}$ \\ ${ }^{1}$ Mohota Science College, Nagpur, Maharashtra, India \\ ${ }^{2}$ Sevadal Mahila Mahavidyalaya, Nagpur, Maharashtra, India \\ Corresponding author : anjaliml@rediffmail.com
}

\begin{abstract}
:
Agriculture in Vidarbha continues to be caught in a vortex of nutrient deficiency in soil, affecting yield of varieties of crops in the region. Though the entire state is considered deficient in iron and zinc, problem is more pronounced in Vidarbha region. The present study was carried out to ascertain the status of micronutrients in soil samples of Umri village, Saoner Tehsil, Nagpur district. The available status of micronutrients. In all ten composite soil samples were collected and analyzed as per standard procedure for assessing micronutrient status of soil. Copper, Iron, manganese, Zinc and Nickel in the soils was found to range from $0.83-1.23 \mathrm{mg} / \mathrm{kg}, 21.18$ to $36.73 \mathrm{mg} / \mathrm{kg}, 96.70$ to $110.34 \mathrm{mg} / \mathrm{kg}, 11.52$ to $19.37 \mathrm{mg} / \mathrm{kg}$ and 0.70 to $0.92 \mathrm{mg} / \mathrm{kg}$ respectively.
\end{abstract}

Keywords: Soil, Micronutrients, Copper, Manganese, Zinc, Iron and nickel

\section{INTRODUCTION:}

Macro and Micronutrients are essential plant nutrients that are found in trace amounts in tissue, but play an important role in plant growth and development.

Without these nutrients, plant nutrition would be compromised leading to potential declines in plant productivity. Of the 17 elements essential for plant growth, eight are micronutrients: boron (B), chlorine $(\mathrm{Cl})$, copper $(\mathrm{Cu})$, iron $(\mathrm{Fe})$, Manganese $(\mathrm{Mn})$, molybdenum (Mo), zinc $(\mathrm{Zn})$ and nickel (Ni). The micronutrients i.e., $\mathrm{Fe}, \mathrm{Cu}, \mathrm{Zn}, \mathrm{Mn}, \mathrm{Co}, \mathrm{Ni}, \mathrm{Mo}$, and $\mathrm{S}$ in soil play a very important role in plant growth, productivity, soil fertility and animal nutrition. The main functions of the micronutrients in living organism are structural components of cell constituents and its metabolically active compounds, in the maintaining of cellular organization, in energy transformation in enzyme action, etc. There is increasing interest from the agricultural community in micronutrient fertilization for a variety of reasons including: 1) soil erosion and long term cropping have resulted in the removal of micronutrients from soils; 2) increasing crop yield generally leads to greater micronutrient removal rates in grain and other harvested products; and 3) the widespread replacement of micronutrient-rich manures with mineral fertilizers has reduced micronutrient addition from fertilizer source.

Vidarbha soil is inherently alkaline with 70-80 percent of soil with $\mathrm{pH}$ exceeding the desirable value. Though phosphorous is present in soil sufficiently, which has been formed from Basalt rock in Vidarbha, being chemically very active nutrient Phosphorous converts into complex compounds in due course of time. Soil should ideally have $\mathrm{pH}$ value between 6.5 and 7.5 for better yield of crops. According to data available with Soil Survey and soil Testing laboratory at Nagpur, soil was found to be 44 percent deficient in iron (Fe) and 40 percent deficient in Zinc ( $\mathrm{Zn})$. With the number of cattle declining over the years, farm yard manure and compost addition to soil is declining, leading to deficiency of both Zinc and Iron. Soil is also marginally deficient in Copper and Manganese.

\section{MATERIAL METHODS:}

The study area, Umri is a village in Saoner Taluka in Nagpur district of Maharashtra state, India. It is located $36 \mathrm{~km}$ towards North from district headquarters Nagpur. $808 \mathrm{~km}$ from state capital 
Mumbai. Umri is surrounded by Kalmeshwar Taluka towards South, Parseoni Taluka towards east, Nagpur Taluka towards south, Sausar Taluka towards North (3). The total geographical area of village is 760.73 hectares.

A total of 10 composite surface soil samples were collected at a depth of $0-20 \mathrm{~cm}$ covering the entire study area. The soil samples collected during the field work were initially air dried in laboratory at room temperature, ground using wooden mortar and pestle, screened through $2 \mathrm{~mm}$ sieve, properly labeled and stored in polythene bags for laboratory analysis. The micronutrients (Cu, Mn, Fe, $\mathrm{Zn}$ and $\mathrm{Ni}$ ) from soil were extracted with 0.005 diethylene triamine penta acetic acid (DTPA) as per method outlined by Linsey and Norvell (1978).

\section{RESULT \& DISCUSSION :}

\section{Copper}

The concentration of Copper in the earth's crust is averaged $28 \mathrm{mg} / \mathrm{kg}$.

The concentration of copper in soils of the studied area ranged from 0.83 to $1.23 \mathrm{mg} / \mathrm{kg}$ with an average value of $1.06 \mathrm{mg} / \mathrm{kg}$. A 0.2 and $50 \mathrm{mg} / \mathrm{kg} \mathrm{Cu}$ were reported as critical and threshold value for $\mathrm{Cu}-$ deficiency and $\mathrm{Cu}$ - toxicity to plant growth

\section{Manganese}

Manganese concentration in the earth's crust is 1000 $\mathrm{mg} / \mathrm{kg}$. The concentration of Manganese in soils of this region lie in the range of 96.70 to $110.34 \mathrm{mg} / \mathrm{kg}$ with an average value of $102.10 \mathrm{mg} / \mathrm{kg}$. A 5.7 and 55 $\mathrm{mg} / \mathrm{kg}$ were reported as the critical limit for $\mathrm{Mn}$ deficiency and threshold value of $\mathrm{Mn}$ - toxicity for plant growth.

\section{Iron}

Iron comprises about 5\% of the earth's crust and is the fourth most abundant element in the lithosphere. The content of iron in the soil samples varied in the range of 21.18 to $36.73 \mathrm{mg} / \mathrm{kg}$ with an average of $29.78 \mathrm{mg} / \mathrm{kg}$. Considering $6 \mathrm{mg} / \mathrm{kg}$ as the critical value of $\mathrm{Fe}$, the soils of studied area was found to be contaminated with a very high level of Fe.

\section{Zinc}

The zinc content of the lithosphere is $67 \mathrm{mg} / \mathrm{kg}$. The concentration of Zinc in the studied samples ranged from 11.52 to $19.37 \mathrm{mg} / \mathrm{kg}$ with an average of 13.86 $\mathrm{mg} / \mathrm{kg}$. Critical limit for Zinc-deficiency in different type of soils for different crops were ranged from 0.4 to $0.8 \mathrm{mg} / \mathrm{kg}$.

A value of $50 \mathrm{mg} / \mathrm{kg} \mathrm{Zn}$ was reported as the threshold value for the plant toxicity. None of the soil of the studied area is contaminated with Zinc.

\section{Nickel}

The natural abundance of nickel in the earth's crust is $40 \mathrm{mg} / \mathrm{kg}$. The concentration of nickel in soils of this region were varied from 0.70 to $0.92 \mathrm{mg} / \mathrm{kg}$ with an average of $0.78 \mathrm{mg} / \mathrm{kg}$. A 0.1 and $50 \mathrm{mg} / \mathrm{kg} \mathrm{Ni}$ in soil were considered as the critical limit, and threshold value of toxicity for plant growth respectively.

All soil samples studied were found to contain Nickel well within the permissible limit.

\section{CONCLUSION :}

Almost all soil samples of this region were found to contain Copper and Nickel well within the limit prescribed. Concentration of Manganese in all the samples was found to be well above the threshold limit prescribed $(96.70-110.34 \mathrm{mg} / \mathrm{kg})$. Soils are contaminated with Iron and Zinc as the concentration of these micronutrients also exceeds the prescribed limit.

\section{REFERANCE :}

Gupta, U.C., Kening, W. and Siyuan, L. (2008) Micronutrients in Soils, Crops and Livestock. Earth Science Frontiers, 15,110-125.

Renwick, A.G. and Walker, R. (2008) Risk Assessment of Micronutrients. Toxicology Letters, 180,123-130

Micronutrients- Soil fertility- the Ohio State University

Yearly Micronutrient deficiency Report, Soil survey and soil testing laboratory, Nagpur. 
Tan, K. H. (2005) Soil Sampling, Preparation and Analysis. Second Edition, CRC Press, Boca Raton.

Reference Lindsay, W L. and Norvell, W A. (1978). Development of DTPA soil test for Fe, Mn, Zn and Cu. Soil Sci. Soc. America J. 42. 421-427.

Rudnick,R. L. and Gao, S.(2003)The composition of the Continental crust, In: holland, H. D. and
Turekian, K. K.,Eds., Treatise on Geochemistry, vol.3, the crust, ElsevierPergamon, Oxford, 1-64.

Patel, K.S., Chikhlekar, S., Ramteke, S., Sahu, B.L., Dahariya, N. S. and Sharma, R. (2015). Micronutrient Status in soil of Central India. American Journal of Plant Sciences,6, 30253037

Table 1 Concentration of Micronutrients in soil samples of UMRI Village

\begin{tabular}{|c|c|c|c|c|c|c|}
\hline \multirow{2}{*}{ S. No. } & \multirow{2}{*}{ Sample I.D. } & \multicolumn{5}{|c|}{ Metal (mg/kg) } \\
\cline { 3 - 7 } & & Cu & Mn & Fe & Zn & Ni \\
\hline 1 & 1 & 1.03 & 103.39 & 36.73 & 14.01 & 0.83 \\
\hline 2 & 2 & 1.17 & 98.48 & 28.29 & 11.47 & 0.92 \\
\hline 3 & 3 & 0.97 & 107.16 & 32.44 & 16.73 & 0.73 \\
\hline 4 & 4 & 0.83 & 96.70 & 22.56 & 12.43 & 0.79 \\
\hline 5 & 5 & 1.23 & 99.37 & 21.18 & 13.92 & 0.81 \\
\hline 6 & 6 & 0.89 & 110.34 & 31.65 & 11.52 & 0.73 \\
\hline 7 & 7 & 1.08 & 108.44 & 30.16 & 12.53 & 0.82 \\
\hline 8 & 8 & 1.25 & 98.34 & 35.74 & 19.37 & 0.70 \\
\hline 9 & 9 & 1.08 & 100.52 & 30.48 & 13.99 & 0.72 \\
\hline 10 & 10 & 1.05 & 98.22 & 28.56 & 12.58 & 0.70 \\
\hline & Average & 1.06 & 102.10 & 29.78 & 13.86 & 0.78 \\
\hline & Critical & 0.2 & 5.7 & 6.0 & 0.80 & 0.1 \\
\hline
\end{tabular}

\section{Graphs}

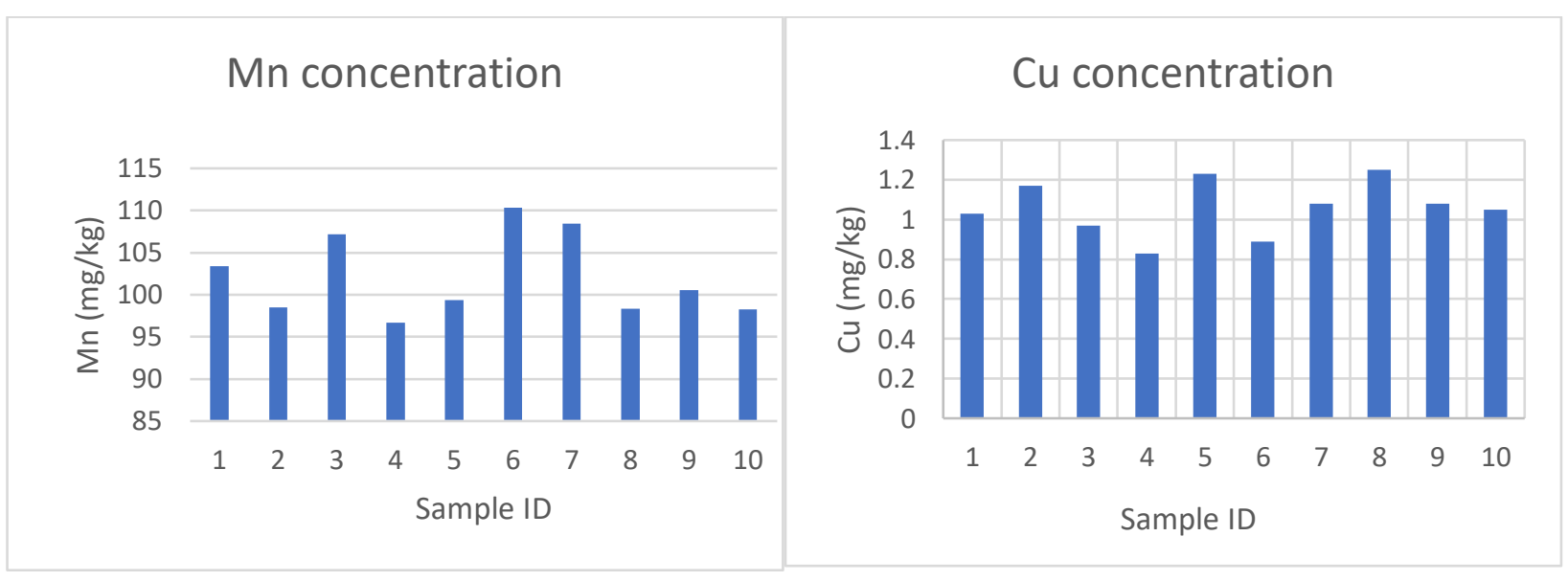



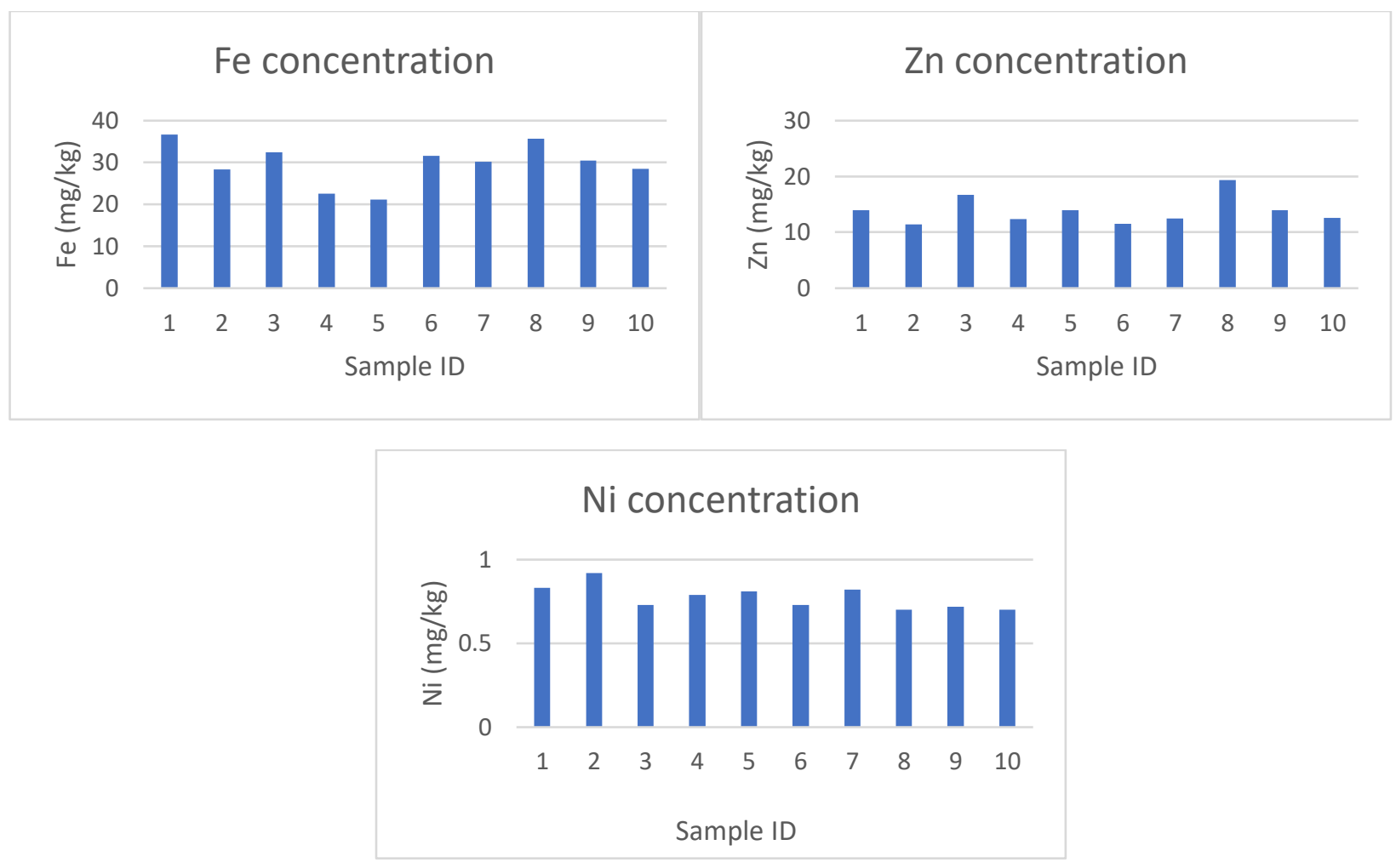